\title{
Influence of prevalent occupational position during working day on occupational lower limb edema
}

\author{
Influência da postura prevalente de trabalho no \\ edema ocupacional dos membros inferiores \\ Cleusa Ema Quilici Belczak', José Maria Pereira Godoy², Amélia Cristina Seidel³, Rubiana Neves Ramos4, \\ Sergio Quilici Belczak5, Roberto Augusto Caffaro ${ }^{6}$
}

\begin{abstract}
Background: The lower limb edema observed in normal people at the end of their working days can vary in intensity and frequency depending on the predominant working positions required to perform different jobs. Objectives: To compare lower limb volumes of volunteers allocated to three study groups, depending on the predominant positions in which they work. Methods: Volumetric assessments were conducted of both lower limbs of 51 people free from vascular disease, allocated to three groups of 17 individuals each by predominant working position: sitting, static standing or alternating between the two. Volumes were measured at the start and at the end of the working day and the differences in volumes were calculated for each group. Means and frequencies were compared using appropriate inferential statistics and correlation coefficients were calculated. Results: The groups were homogenous in terms of sex distribution, age, skin color and BMI. The volumetric data from measurements taken before starting work revealed significant differences between all three groups. Volunteers who predominantly worked sitting down had largest volumes, followed by those who remained standing for long periods and then those who varied between these positions. The frequency of lower limb volume increase $>100 \mathrm{~mL}$ was significantly higher in the group of people who worked sitting down and maintained this position for long periods. Conclusions: Postural edema is more common among people who work sitting down for long periods, among whom it appears that there is a cumulative effect from the position, since they exhibit larger lower limb volumes at the start of the day.
\end{abstract}

Keywords: edema; posture; venous insufficiency; occupational health; working conditions.

\begin{abstract}
Resumo
Contexto: O edema de membros inferiores (MMII) de indivíduos normais, que se observa ao final da jornada de trabalho, pode ser mais intenso e frequente conforme a postura laboral prevalente no exercício da profissão. Objetivos: Comparar os volumes dos MMII de indivíduos alocados em três grupos, conforme a postura laboral prevalente adotada ao longo do dia trabalho. Métodos: Realizadas avaliações volumétricas de ambos os MMII de 51 indivíduos sem doença vascular, que foram alocados em três grupos de 17 indivíduos, considerando a postura prevalente: sentada, ortostática estática e alternada. As volumetrias foram realizadas no início e no término do dia trabalhado, e calculou-se a diferença dos volumes aferidos em cada grupo. Foram utilizadas as estatísticas inferenciais adequadas para comparações de médias e de frequências, e para determinação de coeficientes de correlação. Resultados: Os grupos se mostraram homogêneos em relação a gênero, idade, grupo étnico e IMC. Dados das volumetrias realizadas no início do dia revelaram diferenças significativas entre os três grupos, indicando maiores volumes em indivíduos que trabalham predominantemente sentados, seguidos daqueles que trabalham em pé e dos que alternam essas posições. A frequência de MMII com aumento de volume > $100 \mathrm{~mL}$ foi significativamente maior no grupo dos que trabalham sentados, adotando essa posição por longo tempo. Conclusões: $O$ edema postural é mais frequente naqueles que trabalham sentados por longo tempo, nos quais parece ocorrer, inclusive, efeito cumulativo dessa postura, já que apresentam volumes significativamente maiores já ao início do dia.
\end{abstract}

Palavras-chave: edema; postura; insuficiência venosa; saúde ocupacional; condições de trabalho.

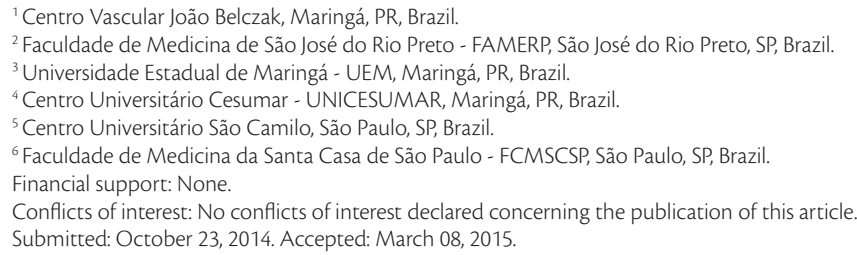




\section{INTRODUCTION}

Since the end of the 1960s, researchers attempting to explain certain venous diseases of the lower limbs (LL) have investigated the predominant body position that people adopt during their normal working days. The earliest studies linked varicose veins with the static orthostatic postures demanded by jobs performed by textile workers ${ }^{1}$ and retail salespeople, ${ }^{2}$ while later studies confirmed an association between the predominant orthostatic position adopted throughout the day and chronic venous diseases (CVD). ${ }^{3-6}$ However, one of these studies found that varicose veins in the LL exhibited a stronger correlation with jobs that require workers to carry weight than with jobs involving an orthostatic predominant posture. ${ }^{2}$ Still other studies failed to detect any type of correlation between CVD and an orthostatic working position, ${ }^{7-8}$ which was later confirmed by the first prospective, population-based study of the subject, which found that the incidence of LL varicose veins was higher among women who spent 8 hours in sedentary activities than among those who spent 4 hours or less in such activities, with no influence on these results from the orthostatic position itself. ${ }^{9}$ Two later reviews, while not systematic, concluded that evidence on occupational risk factors for CVD was still being interpreted erroneously, ${ }^{10,11}$ particularly in view of the fact that the greater part of these studies included in the "venous diseases / varicose veins" category symptoms that were merely suggestive de these conditions, such as LL edema and feelings of heaviness.

As a result, and because increased LL volume may cause true edema, while edema in turn is generally an early sign of CVD, ${ }^{12}$ a new series of investigations have been conducted in attempts to improve understanding of the venous hemodynamic changes that take place in individuals free from symptoms of any type of vascular condition, as a function of the employment activities that they engage in. These studies measured LL volumes, using a variety of techniques, at the start and end of work shifts. For example, Bishara et al. ${ }^{13}$ employed photoplethysmography and detected significant reductions in venous capacitance at the end of the working day, attributing the difference to the fact that veins in the extremities contain large volumes of blood after a prolonged period of standing. Using air plethysmography, Katz et al. ${ }^{14}$ observed changes in LL volume that were probably due to valve dysfunction caused by the effects of daily activities. Belczak et al. ${ }^{15}$ observed significant increase in LL volume in individuals without CVD who remained in orthostatic positions for more than 4 hours per day, using both circumference measurements and water plethysmography. They inferred that vessels suffer harmful effects from gravitational pressure which, in turn, interfere in valve function, contributing to increased venous pressure and causing interstitial edema or internal dilation of vessels. In a later study, ${ }^{16}$ the authors employed water plethysmography to assess volume differences in the lower limb, at $7 \mathrm{AM}, 1 \mathrm{PM}$ and $7 \mathrm{PM}$, in individuals apparently free from CVD and who spent prolonged periods in static positions during their working days, finding that the largest differences were between the end of the morning and the afternoon, and also confirmed these findings with people whose jobs involved a variety of postures (orthostatic, sitting and walking) for similar periods during the course of the day. ${ }^{17}$ Working from these data and following the same line of investigation, this study was conducted to compare differences in LL volume and their relationships to different working positions during the day in people free from venous disease.

\section{METHODS}

A total of 51 people with no signs or symptoms of $\mathrm{CVD}$ or with telangiectasias only $(\mathrm{C} 0$ and $\mathrm{C} 1$ on the CEAP classification, respectively), whose different jobs required either predominantly orthostatic positioning, sitting positions or a combination of orthostatic and sitting positions. These individuals were allocated to one of three study groups, each containing 17 people, depending on their predominant position during the working day. After agreeing to take part and signing free and informed consent forms, all subjects underwent patient history and clinical examination by a vascular clinician. Candidates were excluded from the study if any of the following were detected: peripheral arterial disease, assessed using Doppler ultrasonography to calculate the ankle brachial index and considering results lower than 0.9 as indicative of disease, in accordance with the guidelines for diagnosis of peripheral arterial occlusive disease; ${ }^{18}$ systemic arterial hypertension and/or diabetes mellitus; use of diuretic or hormonal medications; LL edema with a systemic basis, such as congestive heart failure, kidney failure and/or liver failure, myxedema and traumatic or rheumatic joint conditions; lymphedema or routine wearing of elastic stockings, and/or any type of dermatological lesion. A single physiotherapist took volumetric measurements in millimeters for each lower limb of each volunteer at the start and end of each work shift by water plethysmography, using glass basins specially built for the purpose and filled with 
water at room temperature. The differences between measurements taken in the morning and afternoon were then calculated.

The following descriptive statistics were calculated: means, standard deviations and medians for the volume measurements for each group. Means and standard deviations were compared using analysis of variance (Anova) or Student's $t$ test, depending on which inferential statistic was appropriate. The median test was used to analyze the distributions of individuals in each group with volumetric variations greater than or less than $100 \mathrm{~mL}$ (median for the whole sample), and the distribution was then tested using the Chi-square test. Finally, Pearson's coefficients were calculated for correlations between initial volumes and the volumetric differences observed.

\section{RESULTS}

The groups were selected at random, but were nevertheless homogenous in terms of sex distribution, skin color, age and body mass index (BMI) (Table 1). The group of volunteers who predominantly worked sitting down had significantly larger mean volumes for both LL in the morning and at the end of the working day than those who remained standing for long periods and also than those who varied their working position. Similarly, those whose predominant working position was orthostatic exhibited significantly higher mean volumes than people who varied their working position. In contrast, there were no statistically significant differences between groups in terms of mean differences between the volumes measured in the morning and at the end of the day, notwithstanding the fact that these differences were greatest among volunteers who predominantly worked sitting down, followed by those who worked standing up, and were smallest among those who alternated between these positions during their working day. These data are shown in Table 2 and illustrated graphically in Figure 1.

However, when both LL of all volunteers were distributed in terms of whether the difference was larger or smaller than the mean difference for the entire sample (which was $100 \mathrm{~mL}$ for all $102 \mathrm{LL}$ from the 51 individuals in the sample), differences greater than $100 \mathrm{~mL}$ were significantly more frequent in people who worked sitting down than in the LL of people in the other two groups $(\mathrm{p}=0.037)$. No statistical difference was detected between the orthostatic position group and the alternating positions group, although the number of $L L$ with volumetric differences $>100 \mathrm{~mL}$ was larger in the orthostatic position group (Figure 2).

The correlation coefficients (Table 3) show that larger BMI was associated with larger volumes of both LL at the start of the day among those who predominantly worked sitting or standing up, but not among those who alternated working positions, for whom no correlations of this type were detected. On the other hand, there were no significant correlations between LL volume differences and volunteers'BMI, with the exception of a strong negative correlation that was observed for the right legs of the alternating position group only.

In turn, coefficients calculated for correlations between LL volumes at the start of the day and the volumetric difference at the end of the day showed the following: for people who predominantly worked sitting down, the larger the morning volume, the larger the difference in volume in the right leg (but not for the left leg or when both leg measurements are analyzed together); among people who predominantly worked

Table 1. Characteristics of the sample.

\begin{tabular}{|c|c|c|c|c|c|}
\hline \multirow{2}{*}{ Parameters } & & \multicolumn{4}{|c|}{ Predominant working position $\left({ }^{*}\right)$} \\
\hline & & Sitting & Orthostatic & Alternating & $p$ value \\
\hline Female sex (\%) & & $70.6 \%$ & $88.2 \%$ & $100.0 \%$ & $0.653^{1}$ \\
\hline \multirow[t]{4}{*}{ Skin Color(\%) } & Yellow & 0 & $11.8 \%$ & 0 & $0.477^{1}$ \\
\hline & White & $58.8 \%$ & $52.9 \%$ & $64.7 \%$ & \\
\hline & Brown & $29.4 \%$ & $29.4 \%$ & $29.4 \%$ & \\
\hline & Black & $11.8 \%$ & $5.9 \%$ & $5.9 \%$ & \\
\hline \multirow[t]{3}{*}{ Age (years) } & Range & $23-63$ & $24-63$ & $23-64$ & $0.305^{2}$ \\
\hline & Média+Desvio-padrão & $40.0 \pm 12.7$ & $37.8 \pm 11.1$ & $44.9 \pm 12.7$ & \\
\hline & Median & 40 & 35 & 44 & \\
\hline \multirow[t]{3}{*}{$\mathrm{BMI}$} & Range & $22.8-34.0$ & $17.9-36.0$ & $15.4-31.2$ & $0.201^{2}$ \\
\hline & Média+Desvio-padrão & $26.8 \pm 3.1$ & $25.7 \pm 4.2$ & $24.0 \pm 3.4$ & \\
\hline & Median & 25.9 & 25.0 & 24.2 & \\
\hline
\end{tabular}

(1) Chi-square test. (2) Analysis of Variance. ${ }^{*}$ ) Considering both legs for each volunteer. 
Table 2. Means and standard deviations for volumes measured at start (morning) and end (afternoon) of working day, and their respective differences.

\begin{tabular}{lcccc}
\hline \multirow{2}{*}{ Parameters } & \multicolumn{4}{c}{ Predominant working position } \\
\cline { 2 - 5 } & Sitting & Orthostatic & Alternating & $P$ value \\
\hline Initial volume - right & $3,732.9 \pm 414.1$ & $3,480.0 \pm 357.0$ & $3,170.0 \pm 289.5$ & $\mathbf{0 . 0 2 5}$ \\
Final volume - right & $3,847.1 \pm 437.2$ & $3,575.9 \pm 343.9$ & $3,254.7 \pm 307.0$ & $\mathbf{0 . 0 2 0}$ \\
Difference in right volume & $114.1 \pm 52.7$ & $95.9 \pm 49.8$ & $84.1 \pm 34.5$ & 0.265 \\
Initial volume - left & $3,739.4 \pm 443.7$ & $3,478.8 \pm 340.3$ & $3,145.3 \pm 281.2$ & $\mathbf{0 . 0 2 3}$ \\
Final volume - left & $3,855.3 \pm 446.1$ & $3,581.2 \pm 340.8$ & $3,235.9 \pm 293.4$ & $\mathbf{0 . 0 1 9}$ \\
Difference in left volume & $113.5 \pm 52.2$ & $97.6 \pm 51.9$ & $90.6 \pm 35.3$ & 0.390 \\
\hline
\end{tabular}

Correlation coefficients in bold are significant to $p<0.05$.
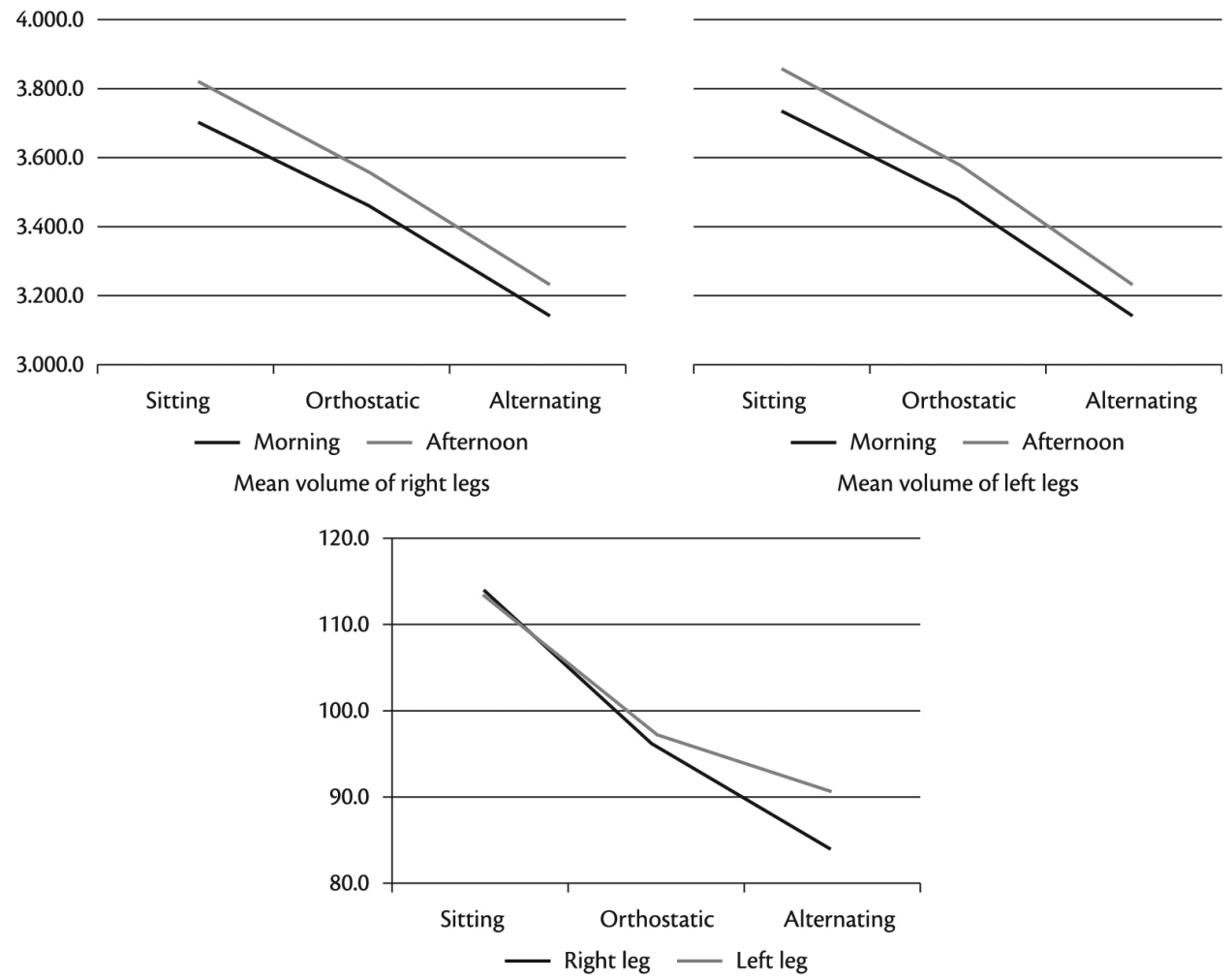

Differences between volumes measured in morning and afternoon

Figure 1. Above: Mean volumes of left and right legs measured at start (morning) and end (afternoon) of work shifts. Below: Differences between morning and afternoon volumes.

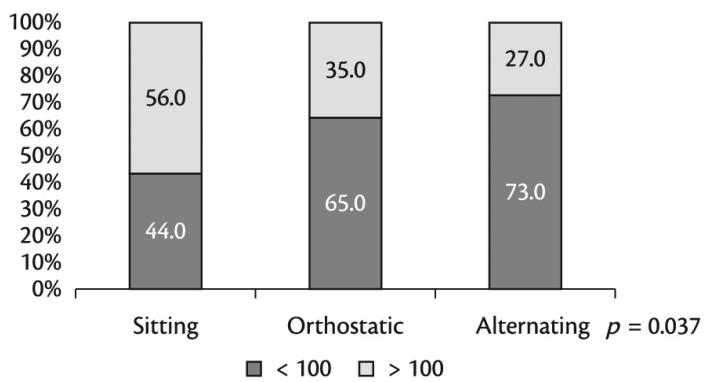

Figure 2. Distribution of relative frequencies of differences between volumes measured at the start and end of work shifts: greater than or less than $100 \mathrm{~mL}$ (median for whole sample). in the orthostatic position, the larger the morning volume, the lower the variation at the end of the day in both LL; whereas, in contrast, among people who alternated their working position, the greater the morning volume, the greater the volumetric variation at the end of the day.

\section{DISCUSSION}

Many studies have already linked the signs and symptoms of CVD, and even CVD per se, to postures adopted for long periods during daily occupational activities and, more specifically, to the orthostatic 
Table 3. Pearson correlation coefficients.

\begin{tabular}{lccc}
\hline \multicolumn{1}{c}{ Correlation tested } & \multicolumn{2}{c}{ Predominant working position } \\
\cline { 2 - 4 } & Sitting & Orthostatic & Alternating \\
\hline BMI $\times$ Initial volume - right & $\mathbf{0 . 5 8}$ & $\mathbf{0 . 6 5}$ & 0.09 \\
$\mathrm{BMI}$ × Initial volume - left & $\mathbf{0 . 6 5}$ & $\mathbf{0 . 6 4}$ & 0.02 \\
$\mathrm{BMI} \times$ Difference in right volume & 0.26 & -0.07 & $-\mathbf{0 . 5 4}$ \\
$\mathrm{BMI} \times$ Difference in left volume & -0.25 & 0.16 & -0.20 \\
Initial volume $\times$ Difference in right volume & $\mathbf{0 . 3 9}$ & $\mathbf{- 0 . 3 3}$ & $\mathbf{0 . 4 5}$ \\
Initial volume $\times$ Difference in left volume & -0.06 & $\mathbf{- 0 . 4 9}$ & 0.29 \\
Initial volume $\times$ Difference in volume of both legs & 0.16 & $\mathbf{- 0 . 4 0}$ & $\mathbf{0 . 3 7}$ \\
\hline
\end{tabular}

Correlation coefficients in bold are significant to $p<0.05$. BMI - Body Mass Index.

position, ${ }^{1-6}$ but other studies have failed to detect sufficient evidence to classify static standing positions as a risk factor for development of CVD. ${ }^{7-11}$ Notwithstanding, it is already well-established that working positions maintained for long periods during the working day can result in increased LL volume, even in people with no signs or symptoms of CVD, and that this increase in LL size can result both from interstitial edema and from internal dilation of vessels. ${ }^{13-15}$ There is also clear evidence that this increase in LL volume observed at the end of the morning is greater than the increase that occurs during the afternoon. ${ }^{16,17}$ Nevertheless, the majority of these studies investigated jobs in which either an orthostatic position or walking is the predominant position maintained throughout the day.

In the present study, possible differences in volume variations during the working day were investigated and compared in terms of the predominant posture adopted when at work. The first finding was that before beginning work, at the start of the day, LL volume was already larger in the group of volunteers who remained sitting for the majority of their working day, followed by those who remained in orthostatic positions, with participants who alternated between these positions while at work exhibiting the smallest volumes. These differences between groups were significant.

Bearing in mind that the groups were homogenous in terms of sex distribution, age, skin color and BMI, it would appear as a valid suggestion that the larger LL volumes among individuals who predominantly work sitting down, measured early in the morning, are predominantly a cumulative phenomena. Although it has been postulated that when sitting down the legs are free to move and can even be stretched and that the seat provides a relatively fixed point of reference, which would make it possible to change trunk positions to promote blood circulation, ${ }^{19}$ it is our understanding that the immobility of LL when sitting causes worse conditions from a phlebological point of view, since ankle immobility precludes calf muscle pump function. In contrast, when standing upright in the orthostatic position, people do not keep their legs absolutely immobile, because they have to move them even to maintain this fixed position which, however minimally, activates the impulse-aspiration pumps, which in turn reduces distal venous pressure. We are not alone in this understanding, as can be illustrated by the fact that airlines are beginning to recommend that passengers on longer haul flights should get out of their seats at regular intervals to exercise the legs, feet and ankles, with the objective of preventing edema and even the occurrence of deep venous thrombosis. ${ }^{20}$ Additionally, our clinical experience has shown us that people who work sitting down for 7 or 8 hours exhibit complaints compatible with chronic venous insufficiency more frequently, and also measurable edema.

Despite the differences in initial LL volume between the groups investigated, there were no differences between them in terms of mean difference in volumes measured at the start and the end of the working day, notwithstanding the facts that these differences were larger among people who work sitting down, followed by those who remained in orthostatic positions all day, and that the smallest differences were detected among people who alternated between these positions. In contrast, when volume differences were analyzed with respect to a $100 \mathrm{~mL}$ cutoff, which was the median for the entire $102 \mathrm{LL}$ sample, there was a significantly higher frequency of LL with difference in volume $>100 \mathrm{~mL}$ in the group of volunteers who worked sitting down, when compared with both of the other groups, between which, in turn, there was no significant difference in frequency distribution. These findings provide a basis for the conclusion that sitting down for long periods does indeed result both in larger LL volumes and in larger differences between volumes measured at the start and the end of the working day. It is known that a normal 
individual in a static standing position exhibits a pressure of around $90 \mathrm{mmHg}$ and that when walking this pressure drops to $30 \mathrm{mmHg}$. When this same healthy individual is sitting down, pressure will be around $52 \mathrm{mmHg}$. If this position is maintained for prolonged periods, as is the case with manicurists and office workers who work with IT, this high pressure will be maintained constantly which, to a certain extent, explains a tendency to accumulate more severe edema and to develop symptoms of chronic venous disease of the LL. ${ }^{21}$

A study that investigated seven traffic control workers who worked standing up and nine who worked sitting down found that both these predominant working positions were associated with postural edema, although it was more frequent among those who worked standing up. ${ }^{22}$ It should, however, be pointed out that the traffic workers allocated to the working sitting down group in that study actually worked patrolling the streets on motorcycles, which is an activity that, despite being conducted in a sitting position, demands active and regular movement of the legs and does not cause prolonged compression of any type to the thighs or the popliteal fascia. However, there is a report of higher frequencies of chronic venous insufficiency in the LL of people who predominantly work sitting down than in the legs of people who maintain an orthostatic position throughout the day. ${ }^{23}$

The findings of the present study also indicate a significant positive correlation between higher BMI and larger volumes of both LL (left and right) at the start of the working day, among those who worked sitting down and also among those who worked standing up, but not among those who alternated between these positions. Although mean BMI was homogenous across the study groups, it should be pointed out that the lowest mean BMI and the smallest range of variation in BMI were both observed in the group of people who alternated between different positions during their working day, which could possibly explain the lack of correlation between these two variables. With regard to this, it is known that obesity has been considered a risk factor for venous abnormalities in the LL, ${ }^{24}$ although some investigations have been unable to confirm this assertion. ${ }^{25}$ In the present study, there was no significant correlation between BMI and quantity of LL volume increase at the end of the day.

Analysis of correlations between initial LL volume and quantity of volume increase measured at the end of the day revealed exhibited different phenomena in different groups. In the group of people who worked sitting down, it was not possible to detect any type of correlation between these variables $(\mathrm{r}=0.16)$. The group of volunteers who worked standing up exhibited a significant negative relationship $(\mathrm{r}=-0.40)$; in other words, the smaller the initial volume the larger the difference at the end of the day. Finally, a significant positive correlation $(\mathrm{r}=0.37)$ was detected for people who alternated between working positions; in other words, differences were greater when initial volumes were larger. These data indicate the need for further studies designed to analyze the factors that are linked with larger differences in LL volumes in people free from venous disease who work in different positions

The present study recorded increased LL volume in all three variants of occupational position analyzed, illustrating that people who work in a specific position for prolonged periods, and particularly those who work in sitting positions, should be given guidance on how to prevent this edema and its consequences. Simple, systematic exercises to move the LL at regular intervals are a useful prophylactic measure.

There is evidence in the literature that the most effective preventative measure is to adopt the habit of wearing graduated elastic compression stockings, ${ }^{26-30}$ even if for just a single period during the working day. ${ }^{28}$ For this measure to be truly effective for preventing edema caused by different prolonged postures and, therefore, for it to be recommended to these workers in a manner that is better targeted at this objective, all that remains is to determine the best level of compression, bearing in mind that consensus recommendations are directed at treating already established lymphatic and venous diseases ${ }^{31}$ rather than for prophylaxis against postural edema.

\section{REFERENCES}

1. Pirnat L. [Systematic studies of the varicose symptom complex in industry]. Zentralbl Phlebol. 1967;6(2):265-75. PMid:5598746.

2. Weddell JM. Varicose veins pilot survey, 1966. Br J Prev Soc Med 1969;23(3):179-86. PMid:5798460.

3. Mekky S, Schilling RS, Walford J. Varicose veins in women cotton workers: an epidemiological study in England and Egypt. BMJ. 1969;2(5657):591-5. http://dx.doi.org/10.1136/bmj.2.5657.591. PMid:5798468

4. Abramson JH, Hopp C, Epstein LM. The epidemiology of varicose veins: a survey in western Jerusalem. J Epidemiol Community Health. 1981;35(3):213-7. http://dx.doi.org/10.1136/jech.35.3.213. PMid:7328382

5. Sisto T, Reunanen A, Laurikka J, et al. Prevalence and risk factors of varicose veins in lower extremities: mini-Finland health survey. Eur J Surg. 1995;161(6):405-14. PMid:7548376. 
6. Tüchsen F, Krause N, Hannerz H, Burr H, Kristensen TS. Standing at work and varicose veins. Scand J Work Environ Health. 2000;26(5):41420. http://dx.doi.org/10.5271/sjweh.562. PMid:11103840

7. Guberan E, Widmer LK, Glaus L, et al. Causative factors of varicose veins: myths and fact: na epidemiological study of 610 women. Vasa. 1973;2(2):115-20. PMid:4702336.

8. Maffei FH, Magaldi C, Pinho SZ, et al. Varicose veins and chronic venous insufficiency in Brazil: prevalence among 1755 inhabitants of a country town. Int J Epidemiol. 1986;15(2):210-7. http://dx.doi. org/10.1093/ije/15.2.210. PMid:3721683

9. Brand FN, Dannenberg AL, Abbott RD, Kannel WB. The epidemiology of varicose veins: the Framingham Study. Am J Prev Med. 1988;4(2):96-101. PMid:3395496.

10. Callam MJ. Epidemiology of varicose veins. Br J Surg. 1994;81(2):16773. http://dx.doi.org/10.1002/bjs.1800810204. PMid:8156326

11. Barnes RW. Vascular holism: the epidemiology of vascular disease. Ann Vasc Surg. 1995;9(6):576-82. http://dx.doi.org/10.1007/ BF02018833. PMid:8746837

12. Perrin $M$, Guex JJ. Edema and leg volume: methods of assessment. Angiology. 2000;51(1):9-12. http://dx.doi. org/10.1177/000331970005100103. PMid:10667637

13. Bishara RA, Sigel B, Rocco K, Socha E, Schuler JJ, Flanigan DP. Deterioration of venous function in normal lower extremities during daily activity. J Vasc Surg. 1986;3(5):700-6. http://dx.doi. org/10.1016/0741-5214(86)90032-7. PMid:3701936

14. Katz ML, Comerota AJ, Kerr RP, Caputo GC. Variability of venoushemodynamics with daily activity. J Vasc Surg. 1994;19(2):361-5. http://dx.doi.org/10.1016/S0741-5214(94)70111-3. PMid:8114195

15. Belczak CEQ, Godoy JMP, Seidel AC, Silva JA, Cavalheri G Jr, Belczak SQ. Influência da atividade diária na volumetria dos membros inferiores medida por perimetria e pela pletismografia de água. J Vasc Bras. 2004;3(4):304-10.

16. Belczak CEQ, Godoy JMP, Ramos RN, Oliveira MA, Belczak SQ, Caffaro RA. Influência do turno laboral na formação de edema dos membros inferiores em indivíduos normais. J Vasc Bras. 2008;7(3):22530. http://dx.doi.org/10.1590/S1677-54492008000300007.

17. Belczak CEQ, de Godoy JM, Ramos RN, de Oliveira MA, Belczak SQ, Caffaro RA. Rate of occupational leg swelling is greater in the morning than in the afternoon. Phlebology. 2009;24(1):21-5. http://dx.doi.org/10.1258/phleb.2008.008042. PMid:19155337

18. Wolosker N, Pereira AH, Frankini AD, et al. Diagnóstico da Doença Arterial Obstrutiva Periférica.J Vasc Bras. 2005;4(3, Suppl. 4):S222.

19. Deliberato PCP. Fisioterapia preventiva: fundamentos e aplicações. São Paulo: Manole; 2002. 382 p.
20. Watson HG, Baglin TP. Guidelines on travel-related venous thrombosis. Br J Haematol. 2011;152(1):31-4. http://dx.doi. org/10.1111/j.1365-2141.2010.08408.x. PMid:21083651

21. Brizzio EO, Pelegrin AD, Belczak CEQ, Mayer MT. Fisiologia do sistema venoso. In: Thomaz JB, Belczak CEQ. Tratado de Flebologia e Linfologia. Rio de Janeiro: Rubio; 2006. p. 37-70.

22. Brito APNP, Rodrigues E, Vianna DL, Fernandes SMS. Investigação de edema postural de membros inferiores em agentes de trânsito. J Vasc Bras. 2013;12(4):289-95.

23. Eifell RK, Ashour HY, Heslop PS, Walker DJ, Lees TA. Association of 24-hour activity levels with the clinical severity of chronic venous disease. J Vasc Surg. 2006;44(3):580-7. http://dx.doi.org/10.1016/j. jvs.2006.05.047. PMid:16950437

24. Labropoulos N, Leon LR Jr. Duplex evaluation of venous insufficiency. Semin Vasc Surg. 2005;18(1):5-9. http://dx.doi.org/10.1053/j. semvascsurg.2004.12.002. PMid:15791546

25. Seidel AC, Mangolim AS, Rossetti LP, Gomes JR, Miranda F Jr. Prevalência de insuficiência venosa superficial dos membros inferiores em pacientes obesos e não obesos. J Vasc Bras. 2011;10(2):124-30. http://dx.doi.org/10.1590/S1677-54492011000200006.

26. Partsch H, Winiger J, Lun B. Compression stockings reduce occupational leg swelling. Dermatol Surg. 2004;30(5):737-43. PMid:15099316.

27. Amsler F, Blättler W. Compression therapy for occupational leg symptoms and chronic venous disorders: a meta-analysis of randomised controlled trials. Eur J Vasc Endovasc Surg. 2008;35(3):366-72. http://dx.doi.org/10.1016/j.ejvs.2007.09.021. PMid:18063393

28. Belczak CEQ, Godoy JM, Ramos RN, Oliveira MA, BelczakSQ, Caffaro RA. Is the wearing of elastic stockings for half a day as effective as wearing them for the entire day? Br J Dermatol. 2010;162(1):42-5. http://dx.doi.org/10.1111/j.1365-2133.2009.09396.x. PMid:19785617

29. Belczak CEQ, Godoy JM, Belczak SQ, Silva MAM, Caffaro RA. Compression stockings have a synergistic effect with walking in the late afternoon to reduce edema of the lower limbs. Int Angiol. 2012;31(5):490-3. PMid:22990513.

30. Blazek C, Amsler F, Blaettler W, Keo HH, Baumgartner I, Willenberg T. Compression hosiery for occupational leg symptoms and leg volume: a randomized crossover trial in a cohort of hairdressers. Phlebology. 2013; 28(5):239-47. http://dx.doi.org/10.1258/ phleb.2011.011108.

31. Stout N, Partsch H, Szolnoky G, et al. Chronic edema of the lower extremities: international consensus recommendations for compression therapy clinical research trials. Int Angiol. 2012;31(4):316-29. PMid:22801397. 
Correspondence Cleusa Ema Quilici Belczak Centro Vascular João Belczak Av. Tiradentes, 1081 CEP 87013-260 - Maringá (PR), Brazil E-mail: belczak@wnet.com.br

Author information CEQB - PhD in General Surgery from the School of Medical Sciences, Santa Casa de São Paulo (FCMSCSP); Head, Centro Vascular João Belczak.

JMPG - Tenured professor and an adjunct professor at the Department of Surgery, Faculdade de Medicina de São José do Rio Preto (FAMERP).

ACS - Associate professor of Angiology and Vascular Surgery at the School of Medicine, Universidade Estadual de Maringá (UEM). RNR - Medical student at Centro Universitário Cesumar (UNICESUMAR)

SQB - Professor of Vascular Surgery at the School of Medicine, Centro Universitário São Camilo.

RAC - PhD in Surgery and an adjunct professor at the Department of Vascular Surgery, School of Medicine, Santa Casa de São Paulo

(FCMSCSP).

Author contributions Conception and design: CEQB Analysis and interpretation: $C E Q B$

Data collection: RNR Writing the article: CEQB, JMPG, ACS Critical revision of the article: $C E Q B, A C S$ Final approval of the article*: CEQB, JMPG, ACS, RNR, SQB, RAC Statistical analysis: SM Overall responsibility: CEQB

*All authors have read and approved of the final version of the article submitted to I Vasc Bras. 